\title{
Health as a right and the care of the self: conception of nursing professionals
}

\author{
Saúde como direito e cuidado de si: concepção dos profissionais de enfermagem \\ Salud como derecho y cuidado de sí: concepción de los profesionales de enfermería
}

\author{
Marcos Andrade Silva' \\ ORCID: 0000-0001-8960-3171 \\ Enéas Rangel Teixeira' \\ ORCID: 0000-0002-1721-2056
}

Eliane Ramos Pereira'

ORCID: 0000-0002-6381-3979

Rose Mary Costa Rosa Andrade Silva'

ORCID: 0000-0002-4310-8711

Renata Carla Nencetti Pereira Rocha'

ORCID: 0000-0003-1053-6231

Sonia Olinda Velásquez Rondon" ORCID: 0000-0002-1583-4265

'Universidade Federal Fluminense, Escola de Enfermagem Aurora de Afonso Costa. Rio de Janeiro, Rio de Janeiro, Brazil. "Universidad Nacional de San Agustin de Arequipa. Arequipa, Perú.

How to cite this article:

Silva MA, Teixeira ER, Pereira ER, Silva RMCRA, Rocha RCNP, Rondon SOV. Health as a right and the care of the self: conception of nursing professionals. Rev Bras Enferm [Internet]. 2019;72(Suppl 1):159-65. [Thematic Issue: Work and Management in Nursing]. DOI: http://dx.doi.org/10.1590/0034-7167-2018-0066

\section{Corresponding Author: \\ Marcos Andrade Silva \\ E-mail: marcosandrade.uff@gmail.com}

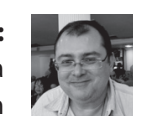

Submission: $02-08-2018$

Approval: 04-20-2018

\section{ABSTRACT}

Objective: To analyze health as a right from the perspective of care of the self, in the conception of nursing professionals. Method: Qualitative study, carried out in a Federal Hospital of the city of Rio de Janeiro, with the participation of 10 nurses and 20 nursing technicians through interviews recorded, transcribed and analyzed in light of the Discursive Textual Analysis. Results: Two categories emerged: Health as the right of professionals and their "non-right" to health; and Care of the self for the health professional: work and torture. Conclusion: There are many challenges to overcome, such as the search for satisfactory public funding, the need to improve the quality of Primary Health Care services, the implementation of a care model compatible with the country's demographic and epidemiological situation; all professionals need an effective endorsement for care of the self, such as their knowledge of the right to health. Descriptors: Right to Health; Nursing; Occupational Health Services; Occupational Health; Occupational Health Policy.

\section{RESUMO}

Objetivo: Analisar a saúde como direito na perspectiva do cuidado de si, na concepção dos profissionais de enfermagem. Método: Estudo qualitativo realizado em um Hospital Federal da cidade do Rio de Janeiro, com a participação de 10 enfermeiros e 20 técnicos em enfermagem mediante entrevistas gravadas, transcritas e analisadas à luz da Análise Textual Discursiva. Resultados: Emergiram duas categorias: $A$ saúde como direito do profissional e o seu "não direito" à saúde; e O cuidado de si para o profissional de saúde: trabalho e suplício. Conclusão: Muitos são os desafios a superar, tais como a busca de um financiamento público satisfatório, a necessidade de melhorar a qualidade dos serviços de Atenção Primária à Saúde, a implementação de um modelo assistencial compatível com a situação demográfica e epidemiológica do país; todos os profissionais precisam de uma efetiva visada para cuidado de si, como o conhecimento de si na busca pelo direito à saúde.

Descritores: Direito à Saúde; Enfermagem; Serviços de Saúde do Trabalhador; Saúde do Trabalhador; Política de Saúde do Trabalhador.

\section{RESUMEN}

Objetivo: Analizar la salud como derecho en la perspectiva del cuidado de sí, en la concepción de los profesionales de enfermería. Método: Estudio cualitativo realizado en un Hospital Federal de la ciudad de Río de Janeiro, con la participación de 10 enfermeros y 20 técnicos en enfermería mediante entrevistas grabadas, transcritas y analizadas a la luz del Análisis Textual Discursivo. Resultados: Se plantearon dos categorías: La salud como derecho del profesional y su "no derecho" a la salud; y El cuidado de sí para el profesional de la salud: trabajo y suplicio. Conclusión: Muchos son los desafíos a superar, tales como la búsqueda de un financiamiento público satisfactorio, la necesidad de mejorar la calidad de los servicios de Atención Primaria de Salud, la implementación de un modelo asistencial compatible con la situación demográfica y epidemiológica del país; todos los profesionales necesitan una efectiva atención para el cuidado de sí, como el conocimiento de sí en la búsqueda del derecho a la salud. Descriptores: Derecho a la Salud; Enfermería; Servicios de Salud del Trabajador; Salud del Trabajador; Política de Salud del Trabajador. 


\section{INTRODUCTION}

In Brazil, health is the right of everyone and the duty of the State, which must elaborate public policies for prevention and assistance, in order to provide integral care through the participation of society and the promotion of a regionalized and decentralized network. In this sense, in order to enable a broader range of services to citizens, Law 8.080/90, which created the Brazilian Unified Health System (SUS - Sistema Único de Saúde), was sanctioned, opposing the biomedical model in a perspective of legitimation in the 1988 constitution $^{(1)}$.

Nursing professionals, like all citizens, are also reached by SUS and participate as agents and, sometimes, as users. We have enormous challenges insofar as the Brazilian nursing has an important role in the defense of health with equity and quality of life, assuming a practice based on care ${ }^{(2)}$. For this reason, the right to health involves the issue of human rights and respect for human dignity ${ }^{(3)}$.

The issue of health as a right is a subject that stands out for its sharp politicization and strong presence of social groups of pressure that show strong interests imbricated in this problematic that assumes increasingly plurals and multisemic contours, not allowing its reduction to simple formulas and resisting analyzes and milestones already established. In fact, health poses itself as a "right to be, not only relative to the level of care of the health system or as a technical procedure"(4).

The health of workers working in the Brazilian Unified Health System is an important focus of interest of the Ministry of Health. As a fundamental advance in the health of workers in this scope, it is worth mentioning the designation of guidelines of the Política Nacional de Promoção da Saúde do Trabalhador do Sistema Único de Saúde - SUS (National Policy for the Promotion of Occupational Health of the Unified Health System - SUS) ${ }^{(5)}$. Until then, the health of SUS workers was supported by general worker health legislation. This policy aims to promote the improvement of the health conditions of the SUS worker, by addressing the general and specific aspects of the environments and work organization that may lead to the occurrence of health problems, the empowerment of workers social actors of these transformations, and by guaranteeing access, actions and services of integral health care. This policy is based on the prerogatives that the quality of work and the promotion of workers' health result, among other actions, from the existence of career plans, positions and salaries, as well as Permanent Education.

According to this Policy, there is an emphasis on the deprecation of work links, the assignment and provision of workers, and the existence of work environments and processes that are appropriate to the specifics of the services. It is important to highlight the scope and purpose of the National Policy for the Promotion of Occupational Health of the Unified Health System, which are linked to the areas of Occupational Health and Work Management and Health Education, establishing a strategic articulation for the development of the SUS and the commitment of managers, workers and employers with the quality of work, and the valorization of workers. Such a SUS policy is often far from the reality of the health worker.

The subject who enjoys health as a right is also the one who is better able to live the aesthetics of existence, through which the subject becomes the object of his invention and self-constitution ${ }^{(6)}$. It should be considered that this is a challenge of more than a mechanical and immediate relationship, but an invitation to reflection, because we need to think and remember that health is a right and at the same time a conquest. Therefore, it is important to treat the problem, justifying an investigation that flee from the pre-established categories that can think of the care restricted to the body, but it is also necessary to think of the care as knowing yourself.

In this perspective, the following research question guided the study and allowed the elucidation of this problem from the understanding about the health issue as a right of the nursing worker in the SUS context. What are the discourses of nursing workers among them, nursing technicians and nurses, about care of the self in the context of health as a right?

It should be pointed out that the research is in line with the Agência Nacional de Prioridades de Pesquisa em Saúde (National Agency for Priorities in Health Research) ${ }^{(7)}$ to studies on social control in health in its sub item that addresses the satisfaction of users and workers in relation to health policies, programs and services. Thus, the question of the right to health is related to worker satisfaction and the policy that the same experiences in health services.

\section{OBJECTIVE}

This study aims to analyze the issue of health as a right from the perspective of care of the self in the conception of nursing professionals.

\section{METHOD}

\section{Ethical aspects}

It is a part of the thesis: "Saúde como Direito e Cuidado de si na perspectiva dos Trabalhadores de Enfermagem: um estudo a partir da Hermenêutica de Foucaul" defended in the Graduate Program in Health Care Sciences of the Universidade Federal Fluminense. Because it is a research issue involving human beings, the ethical aspects were respected according to Resolution $466 / 2012^{(8)}$ of the National Health Council (Conselho Nacional de Saúde), beginning after examination and approval of the Research Ethics Committee of the proposing institution.

\section{Type of study}

This is a descriptive, qualitative study, carried out through Discursive Textual Analysis and based on Michel Foucault's framework to the care of the self.

\section{Theoretical-methodological framework}

The meaning of care of the self itself refers to care as a concrete, precise and particular application of the rule that bound the whole care of the self itself. The sense of this care is thus said by Foucault: "you must attend to yourself, you must not forget yourself, you must take care of yourself"(9).

The care of the self is not simply a concern, but "a whole set of occupations"(10) or, also, a regulated occupation, a work with procedures and objectives. Thus, this care of the self "implies labor" that implies in time to practice it in an exercise of itself, and in all 
ancient philosophy, the care of the self was considered as duty and technique, containing a degree of fundamental obligation.

To do so, it encompasses a set of very zealous procedures: "The care of the self, for Epictetus, is a privilege-duty, a gift-obligation that ensures our freedom while forcing us to take ourselves as the object of all our diligence ${ }^{\prime \prime(10)}$, an indispensable attitude for all.

\section{Research setting}

The research was carried out with nursing professionals, composed of nursing technicians and nurses, who work in a federal public hospital linked to the Ministry of Health, located in Rio de Janeiro State, being considered a reference in the state in the area of Orthopedics, performing, monthly, more than 2 thousand emergency care and another 12 thousand in the outpatient clinic. The hospital carries out around two thousand emergency room visits every month and about 800 surgeries. In the ambulatory, they are, on average, 12 thousand monthly visits. The hospital performs around 15 thousand hospitalizations per year and has more than 5 thousand employees of great technical capacity and has become increasingly a center for teaching, research and training of new health professionals.

\section{Data source}

Thirty nursing professionals participated in the study, of which 10 were nurses and 20 nursing technicians, selected through nonprobabilistic sampling for convenience of the "snowball" type. The inclusion criteria were: nursing professionals, that is, nurses and technicians who are cared for in the hospital's occupational health outpatient clinic and with more than two years of professional experience (as a minimum period for engagement as a worker inserted in the dynamics of the institution). As an exclusion criterion, it was applied to those who do not belong to the institution's permanent staff.

\section{Collection and organization of data}

Data collection took place in the period from January to June 2017, at the hospital's own occupational health clinic, because it is a place where workers who need care and also according to their preference come to work.

Recorded interviews were conducted with an average duration of 30 minutes, containing closed questions for the characterization of the participants and open questions that focused on aspects related to the right to health and the care of the self for nursing professionals.

\section{Procedure and analysis of data}

The data analysis process was based on the interview transcripts, using the analysis based on the Discursive Textual Analysis (DTA) ${ }^{(11)}$, composed of four focuses: 1 ) disassembly of the texts: the participants' answers were examined; 2 ) establishment of relations: the responses were grouped, elaborating the categories; 3 ) capture of the emerging new: elaboration of a metatext, interpreting the meanings and relating them to the original corpus; 4) self-organized process: movement of a new text through theoretical dialogues and new understandings about the phenomenon studied, from the framework of Michael Foucault.

\section{RESULTS}

Predominantly, the participants of this research had a 32-37 year age group (40.0\% of cases), a married civil status (63.3\%), an evangelical religion (55.3\%) and declared themselves without a political orientation $(73,8 \%)$. Seven had a specialization course (23.3\%) and one master (3.3\%). The most frequent professional activity time is between 8 and 12 years (37.9\%).

The analysis of the data allowed to identify two categories: one related to health as a constitutionally existential right, but in practice, there are still obstacles of several orders to be exercised, and another about the care of the self as a right to health, but the body of the subject to suffer with difficulties in the exercise of the right to health becomes a tortured body.

\section{Category 1- Health as the right of professionals and their "non-right" to health}

The category in question shows the discourse of the health worker, a nursing professional, on the contradiction and disagreement existing in the law itself, which ensures the constitutional right in which health is a right of all and the duty of the State. In practice and in living this Law is affected.

Right to health is a right of everyone, in the constitution it is written that everyone has a right to health and it is the duty of the state, everyone has a right to health, but so in my work, I work in a public hospital, I do not see this right widely for everybody. (N1)

Just like the government says everyone's health, so I guess we do not even have to say much about it. Health is a basic requirement for any Brazilian. (N7)

In fact, it is a matter of thinking about the standard identity that each worker has been assuming to continue in life and in the labor market, as a professional. In this perspective, it is also necessary to reflect the macro and disciplinary microphysics existing in each of these settings that it operates.

I think right nowadays in my area of action, people do not have that much right this way, widely, for everyone. It's not everyone's right. (N1)

The right of the health worker is apprehended as 'non-right', a 'non-place'. As it exists in the form of the Law, it does not yet guarantee its operationalization for all, nor do they feel'cared for' in this sense:

It is not a priority precisely because of work, right, this contingency of work, is a part is a thing unfortunately secondary is left behind, right?(N9)

I do not use the right, although knowing it, having it, but I do not use it. (N10)

We have no right to professional health, there is hardly a glance that does something for the real people, right? (N4)

There is a worker who limits himself with a single sentence when he brings the discourse of pain when asked about the place of the right to health in his professional life: Lastly. (N6) It is the indignation of an existence that brings to the worker himself 
Health as a right and the care of the self: conception of nursing professionals Silva MA, Teixeira ER, Pereira ER, Silva RMCRA, Rocha RCNP, Rondon SOV.

the consciousness of the'non-place' of the right to health, a true exclusion of aesthetic values.

In fact, it is a matter of understanding that the professional feels deprived of rights, of the possibility of exercising the aesthetics of his existence, since in some cases the professional makes double journey for the sake of survival. The place of the right in health is, in some cases, replaced by the financial place:

I try to put it first, but it's not in the first place, you end up solving a lot of things first, in fact it ends up in second or third place, because we cannot do it, it always ends up giving priority to the financial part. You cannot find it here, you end up giving priority to work and end up leaving for later the care of the self. (N3)

I do not usually think about it very much, sometimes we even forget about that part, it is more linked to the professional question with patient and forgets a little about it there. (N2)

Forgetting the right and its place is to forget the citizenship itself. It's forgetting the place itself. It is almost an escape from the aesthetics of existence. Amidst these conditions of possibility, one questions: How to realize the production of oneself as the artisan of the beauty of his life, making this a work of art?

Other workers discourse, showing that the 'non-place' of the right to health takes the form when the subject neglects his own health to the detriment of the client's health, that is, the sick professional takes care of the sick patient:

My health as a professional, I think it does not count much because as the colleague talked there before, you have the flu, you have a headache, sometimes you go from what you are feeling, from your health to take care of the other. So I think the health professional, I also, have neglected our health a lot. It's complicated. (N7)

It is a matter of discourse about the erasure of the right to health or of its own negligence in order to maintain itself.

The discourse on health as a right rekindles the issue of accessibility and also the social issue that acts there as a background:

Accessibility, by the public health system, is more accessible not only to us, to the people, but especially to all the professionals, who today have a great difficulty to achieve. (N9)

Thus, it is understood that talking about health as a right for some is talking about having access to health and, above all, being able to enjoy this right in the place where it carries out its activities without having to look elsewhere:

You have access to health. And what is having access to health? When you need to have the resources to your availability, especially as it is aimed at our area, people who need and work inside, I think should not be so marginalized, because you work in a health institution, you have to go out there outside is very complicated. So, I think this sums up well. (N7)

In this way, the worker once again sees the origin and importance of health as a right, but the question that arises is the operationalization of this. It's the challenge that comes up all the time.:
Health is a right really, business is this right to be respected because it is not respected. We do not find service in much of the place. (N3)

\section{Category 2- Care of the self for the health professional: work and torture}

The research brings to light the discourse of the care of the self in the life of the health worker, of the nursing professional. The body that appears in the perspective of the care of the self is also the one that transfers to the institution the protagonism of the care of the self insofar as it understands that care is the role of the Institution.

I think it's not well publicized in the hospital despite having a specific place for it and we end up not getting too interested, because it's like not having an initiative, do not encourage it. (N2)

The absence of this place once again reappears as a tonic in the life of health workers, being its own form of subjectivation of the discourse of this 'non-place' of the care of the self and of almost its non-preservation:

Look, I'm not careful so much, I have my spine swollen now. Now that I'm giving a little bit of priority to me, because I have a problem in the spine, because all this time I've been picking up too much weight and failing to preserve myself, understood? (N3)

Standing before these workers is to be faced with discourses produced from a praxis that makes us consider innumerable aspects of the world of work in relation to the place that occupies the care of the self in the professional life of the subject:

In the professional life? Here it comes first that I have to take care of others. (N9)

The body also relates the care of the self to low pay as survival is amalgamated into conditions of financial survival. It is, therefore, the care of the self that evokes financial health. For the worker, taking care of himself is the care mediated by the resource/financial apparatus. There is no way to take care of yourself without resources:

Look, I'm going to tell the truth, I think everything is linked to my work, everything is linked to my salary [...] my health is directly linked to this, speaking in particular my, my health is linked to this [...] So we have to find other ways to earn, or we work harder than we can. That which breaks our physical and mental health. (N8)

I think so, people already work so hard, they already have such a difficult life. I think the least people should have is the right to treat themselves, it's the right to feel something. (N1)

Nursing workers also address the emergence of psychosomatic, occupational, stress-induced:

[...] Most illnesses, many diseases we have are occupational, are diseases produced at work, are diseases produced by stress, by the sedentary life, by the life that people take. So, the right to health, people had to have this access. (N1) 
You almost have no right to take care, you see many professionals developing the burnout syndrome. It is overwork, stress related to overwork, only so, it is complicated for you to treat yourself. (N6)

The care of the self refers to the discourse of the deceased body. The worker's discourse shows the need for care that goes beyond the boundaries of the biological body, the physical body, but also encompasses the psychic:

Thus, we work with health, we are directly linked to the suffering of the person, the disease. We try not to take all this suffering into our lives ... I think that here should be a better follow-up, even for the health of the worker, we could have psychological care, this has been said several times, because people deals with death every day. (N1)

\section{DISCUSSION}

When we reflect on the issue of law and its corollaries, and on its visibility or invisibility, it should be noted that this appropriation allows the strategies developed by them, especially in the perspectives of health, economy and development, to have as reference parameter the rights humans.

Health and human rights permeate the socio-historical context of workers in the health field. The right to health is also aligned with the fact that health is promoted, so take care of itself, and consequently, knowing yourself. It is understood that the concept of health promotion, based on social determinants, is effectively aligned with human rights principles such as social participation, accountability, transparency and non-discrimination ${ }^{(12)}$.

It should be emphasized that the right to health, the care of the self and the self-knowledge of the public policy system consists in the adoption of human rights norms and standards by both national and international policy makers. Indeed, the right to health is present in the Universal Declaration of Human Rights. Health is defined as a condition for a life worthy and indispensable for the enjoyment of other rights, such as equality, education, freedom, integral components for a healthy life ${ }^{(3)}$.

Each society has its regime of truth, its "general politics" of truth, that is, the types of discourse that accept and make true, the means by which each is sanctioned, the techniques and procedures valued in the acquisition of truth , the status of those who are charged with saying what counts as true.

In this sense, it is necessary to think of society as a whole that involves health, labor, law and care of the self, in order to generate inflection and reflection about the struggle for the fundamental rights of the health worker in the consolidation of a humanized health policy. These workers need to appropriate their governance, participate in institutional decisions, and actually make decisions that imply collective decisions.

Indeed, in access to health, there is a need to create intersectoral instances beyond the field of health, which combine their resources in the formulation of public policies that provide the guarantee of the full exercise of social rights by all citizens of our society and of the planetary community ${ }^{(13)}$.

It should be understood that, despite a global agenda for health as a right, there is still a need for reforms in global and national governance, as well as for the participation of civil society in right to health and its social determinants ${ }^{(14)}$
If the worker is not allowed to invest in knowledge, in qualification (pedagogical sense), if there is no engagement in politics, due to the obsolescence questioned by the power that governs the system of work in health, the individual does not exercise governmentality, that is, he would not exercise the care of the self in the Foucaultian sense ${ }^{(15)}$.

In the workers' discourse, there are those who refer to the care of the self negatively in terms of "neglect"; "unfortunate". It is also a way of subjectifying the experience of the aesthetics of existence, of being constituted to the extent that the worker also makes a selfcriticism. These discourses that come from the praxis of the worker need to be considered, both those that relate the care of the self as a positive thing as those that relate it to negative expressions in the sense of finding that it does not actually occur in their existence.

It is imperative that this "forgetfulness" was conceived by the health worker as negligence and, in Foucault's ${ }^{(15)}$ thinking, a "self-neglect", a "lack of self-care". Although the worker recognizes that the conditions of possibilities offered are incompatible with the right to health and with the own care of the self, there is a self-awareness of negligence on the part of the same.

This place and at the same time'non-place' is a call for a life-long struggle, since we are a process in movement and also a product of new forms of subjectivation and therefore, u-topos can also be the place the transformative encounter, the appropriation of the dream, the struggle and the very aesthetics of existence.

The health worker reinforces the discourse of not having the right to health, of not being able to take care and of the appearance of diseases in the body by the absence of the care with the same one. The body becomes sick and at the same time the professional once again relates the care of the self to self-care. Overwork is also related and amalgamated to the discourse of the body. The denial of the right to health and the right of the body is a cruel tonic.

In fact, we can note the recent revival of contemporary tortures by our health workers when we ask each of them about the care of the self. The care of the self refers to the discourse of the deceased body, the body that must deny the right to self and be punished ${ }^{(16)}$.

The worker's discourse shows the need for care that goes beyond the boundaries of the biological body, of the physical body, but also encompasses the psychic.

If we make a comparison with the question of the health worker, we see that he also carries a deprecated body insofar as the world of work offers its challenges as stratification, inequality $^{(17)}$ and, consequently, its tortures.

The professional feels subjected to a whole massacring context that turns him into a true machine of work and that does not allow the own care of the self. The power in Foucault ${ }^{(16)}$ represses and at the same time brings as corollaries the effects of knowledge and truth.

In this sense, although the professional has rights in the form of the Law, the challenge is that these must be "won" to be lived, as there is an infringement of the rights and legislation that should protect the worker ${ }^{(18)}$.

The torture of the worker assumes an objective but also subjective character in which the torture of the body can begin with the torture of the soul ${ }^{(19)}$. The recognition and change of this reality are possible from the monitoring of workers' health as a tool for the construction of indicators that allow the identification of the workloads involved in the process of illness and the characterization of the worker's morbidity profile ${ }^{(20)}$. 
The discourse of health workers is permeated by self-relation with care, with suffering, with the person and his illness, the discipline imposed by work, the law that does not favor the worker to "stop" for the care of the self. At this moment, the docile body reappears with full force, albeit under protest. Intimate protest is not enough to interrupt the very "letting itself" shape the body that is imploded, the soul whose representations are manipulated, the body that is trained ${ }^{\prime \prime(9)}$.

The health of the worker therefore involves a range of dimensions, which goes through the question of corporeality and, therefore, many aspects related to his life in society, family and the care of the self with himself. However, it should be noted that the worker often faces challenges and that he is unaware of his rights and sometimes his duties as well.

However, although these workers face various adversities in the field of the right to health, they have not lost sight of the dimension of the care of the self, which is very important for the very continuity of the struggle for the care of the self and how to know yourself in that context.

One must think of health as a right also of health workers working at the front line of care. However, there is to some extent invisibility on the part of the workers themselves that this health care is not only directed to the body, but also related to the knowledge of self, when knowing itself. It is as if, historically, by the inheritance of the biomedical model itself, we were left with certain "blindness" that caring for oneself is taking care of the body and it is not at stake to know oneself. Knowing yourself would therefore be outside the question of the right to health, self-knowledge and the care of the self.

It is a matter of thinking of the involvement of the word "care" referring to itself and once again we say that this "self" is not a selfish sentence, but an occupation of self that, when it comes to itself, also turns to the other, because "The care of the self implies a certain way of attending to what we think and what takes place in our thought"(9).

In fact, taking care of the other requires fundamentally caring for oneself and in the same order, knowing oneself, meeting oneself. It is a knowledge that is prerogative to others as aesthetic and as ethics and thus, the art of caring for oneself and, therefore, a"singular, transcendent relation of the subject to his surroundings, to the objects he has, as well as to the others with whom he relates, to his own body and, ultimately, to himself ${ }^{\prime \prime(9)}$.

Thus, the question of the right to health, in the perspective of the care of the self as an aesthetic of existence, is a challenge for the worker, because it places him in the face of the aesthetic but ethical challenge of care, namely: care of the self that involves relationships with others; in the way of taking care of oneself and in the way of caring for others, Foucault warns: "one should not pass on the care of others in front of the care of the self; the care of the self comes ethically first, insofar as the relation to itself is ontologically primary"(10).

Therefore, it should be understood that the issue of health as a right from the perspective of the care of the self in nursing professionals' conception concerns the issue of human rights that still need to be considered as a priority in the world of work and in the scientific, technological and economic conditions. Much has already been achieved, but there are still many challenges ${ }^{(21)}$.

The worker, as a citizen, is also a citizen of rights and the right to health is a constitutional prerogative. However, it should be emphasized that health care involves not only the act of caring for the body, but also, and above all, caring for oneself in the sense of knowing oneself. Knowing yourself is also health, it is also healthy. To know oneself is to meet oneself, and to know oneself is to know its powers, possessions and also its own limits. Knowing oneself also involves to some extent knowing your rights, and these need and must be respected for the full exercise of one's freedom. It is exercise of citizenship and at the same time fight for their own acquired rights.

In order for the professional exercise to be carried out in good conditions, it is necessary for the health worker to be in a healthy condition to perform his or her job, as well as adequate safety in the workplace, since the occupational hazards, being these biological, physical, chemical, ergonomic and mechanical. Therefore, taking into account the health promotion and prevention of these workers, the risks present in the workplace should be identified, thus minimizing the consequences that exposures to risk factors tend to provide in the lives of these workers.

On the other hand, it is urgent that the worker admits as a possibility a relation of self to himself, which implies a selfgovernment and a particular attitude of his or her existence untied by normatizations and legal ruptures that curb an effective aesthetic of existence as an art of living.

\section{Study limitations}

The limitations present in the study are recognized because they were carried out in a single context. Thus, it is necessary to carry out new studies in other places, in order to verify if these barriers and facilitators occur in other health spaces, since this study was carried out only in a single Brazilian city and context that does not mean that the reality found is the same in other Brazilian municipalities.

\section{Contributions to the sector of Nursing or Public Policy}

It was verified that the nurse committed to the right to health and the care of the self will be able to effectively intervene in the improvement of the health of the worker, especially in issues related to the role of nursing workers, SUS users and in the prevention of health problems. The aim of this study is to contribute to workers' health as they move their rights to health and their relationships with the care of the self, which implies the promotion of worker health and the implementation of public health policies that are inclusive of health workers.

\section{FINAL CONSIDERATIONS}

There are many challenges to overcome in the field of Nursing Worker Health, such as: the search for satisfactory public funding; the need to improve the quality of Primary Health Care services; the implementation of an assistance model compatible with the country's demographic and epidemiological situation, all of which need an effective endorsement of the care of the self, as self-knowledge in the search for the right to health.

It is necessary that public policies and management services are attentive and are increasingly involved with measures that can effectively face the challenge of transforming the law into something that is effectively dynamic, in a continuous movement of transformation in a culture of self, contributing to a culture of valorization of the subject, aiming at the practice of the right to health and the care of the self of nursing workers. 


\section{REFERENCES}

1. Souza KMJ, Seixas CT, David HMSL, Costa AQ. Contributions of Public Health to nursing practice. Rev. Bras. Enferm [Internet]. 2017 Jun [citado 2018 Jan 16] ; 70( 3 ): 543-549. Available from: http://www.scielo.br/pdf/reben/v70n3/pt_0034-7167-reben-70-03-0543.pdf

2. Sena RR, Seixas CT, Silva KL. Practices in Community Health Toward Equity: contributions of Brazilian Nursing. Adv Nurs Sci [Internet]. 2007 [cited 2016 Dec 10];30(4):343-52. Available from: https://www.ncbi.nlm.nih.gov/pubmed/18025869

3. Guerra K, Ventura M. Bioética, imigração e assistência à saúde: tensões e convergências sobre o direito humano à saúde no Brasil na integração regional dos países. Cad Saúde Coletiva [Internet]. 2017 Mar [cited 2018 Jan 16];25(1): 123-9. Available from: http://www.scielo. $\mathrm{br} / \mathrm{pdf} / \mathrm{cadsc} / \mathrm{v} 25 \mathrm{n} 1 / 1414-462 X-c a d s c-1414-462 X 201700010185 . p d f$

4. Freitas IBA, Meneghel NA, Selli L. The construction of care by the health team and the caretaker within a home-care program for bedridden patients in Porto Alegre (RS, Brazil). Ciênc Saúde Coletiva [Internet]. 2011 [cited 18 Dec 2016];16(1): 301-10. Available https://www.ncbi.nlm. nih.gov/pubmed/21180837

5. Ministério da Saúde (BR), Gabinete do Ministério. Portaria n 1.823, de 23 de agosto de 2012. Institui a Política Nacional de Saúde do Trabalhador e da Trabalhadora [Internet]. Diário Oficial da União: República Federativa do Brasil, 2012. Aug 24;Seção 1:46-51.(about 1 screen). Disponível em http://bvsms.saude.gov.br/bvs/saudelegis/gm/2012/prt1823_23_08_2012.html

6. Ventura CAA; Mello DF; Andrade RD; Mendes IAC. Aliança da enfermagem com o usuário na defesa do SUS. Rev Bras Enferm. [Internet]. 2012 [cited 2018 Feb 06]; 65(6):893-8. Available from: http://www.scielo.br/pdf/reben/v65n6/a02v65n6.pdf

7. Ministério da Saúde (BR). Agenda Nacional de Prioridades de Pesquisa em Saúde. [Internet]. Brasília; 2015 [cited 2017 Apr 16]. Available from: http://brasil.evipnet.org/wp-content/uploads/2017/07/ANPPS.pdf

8. Ministério da Saúde (BR), Conselho Nacional de Saúde. Resolução n 466, de 12 de dezembro de 2012 Aprova as diretrizes e normas regulamentadoras de pesquisas envolvendo seres humanos [Internet]. Diário Oficial da União: República Federativa do Brasil; 2013 [cited 2017 Sept 03] Jun 13; Seção 1:59 (about 10 screens). Available from: http://conselho.saude.gov.br/resolucoes/2012/Reso466.pdf

9. Foucault F. Hermenêutica do sujeito. 4 ed. São Paulo: Martins Fontes; 2014. 528 p.

10. Foucault F. História da sexualidade: o cuidado de si. 15 ed. Rio de Janeiro: Paz e Terra; 2017. 320 p.

11. Moraes R, Galiazzi M. Análise textual discursiva. 3ed. Ijuí (MG): Unijuí; 2016. p. 264.

12. Neves SP, Heller L. The right to water and sanitation as a tool for health promotion of vulnerable groups. Ciênc Saúde Coletiva [Internet]. 2016 June [cited 2018 Jan 19]; 21(6):1861-70. Available from: http://www.scielo.br/pdf/csc/v21n6/en_1413-8123-csc-21-06-1861.pdf

13. Fiorati RC, ARA, Souza LB. Social inequalities and access to health: challenges for society and the nursing field. Rev Latino-Am Enferm [Internet]. 2016 [cited 2018 Jan 16]; 24:e2687. Available from: http://www.scielo.br/pdf/rlae/v24/pt_0104-1169-rlae-24-02687.pdf

14. Buss PM, Magalhães DP, Setti AFF, Gallo E, Netto FAF, Machado JMH, et al . Saúde na Agenda de Desenvolvimento pós-2015 das Nações Unidas. Cad Saúde Pública [Internet]. 2014 Dec [cited 2018 Feb 06] ; 30( 12):2555-2570. Available from: http://www.scielo.br/pdf/csp/ v30n12/0102-311X-csp-30-12-02555.pdf

15. Rohden L, Kussler LM. Filosofar enquanto cuidado de si mesmo: um exercício espiritual ético-político. Trans/Form/Ação [Internet]. 2014 July [cited 2018 Feb 06]; 40(3): 93-112. Available from http://www.scielo.br/pdf/trans/v40n3/0101-3173-trans-40-03-0093.pdf

16. Silva JP. Poder e direito em Foucault: Relendo vigiar e punir 40 anos depois. Lua Nova [Internet]. 2016 Apr [cited 2018 Feb 06]; 97: 139-171. Available from http://www.scielo.br/pdf/ln/n97/0102-6445-In-97-00139.pdf

17. Santos JAF, Ribeiro LVF. Emprego, estratificação e desigualdade. Estud Av [Internet]. 2016 Aug [cited 2018 Feb 06]; 30(87): 89-102. Available from: http://www.scielo.br/pdf/ea/v30n87/0103-4014-ea-30-87-00089.pdf

18. Carvalho G. A saúde pública no Brasil. Estud Av [Internet]. 2013 Aug [cited 2018 Feb 06]; 27(78): 7-26. Available from: http://www.scielo. $\mathrm{br} / \mathrm{pdf} / \mathrm{ea} / \mathrm{v} 27 \mathrm{n} 78 / 02 . \mathrm{pdf}$

19. Rebouças GM. O avesso do sujeito: provocações de Foucault para pensar os direitos humanos. Opin Juríd. [Internet]. 2015 [cited 2018 Feb 06];14(28):45-61. Available from http://www.scielo.org.co/pdf/ojum/v14n28/v14n28a03.pdf

20. Santana LL, Sarquis LMM, Brev C, Miranda FMD, Felli VEA. Absenteism due to mental disorders in health professionals at a hospital in southern Brazil. Rev Gaúcha Enferm [Internet]. 2016 [cited 2018 Feb 06] ; 37(1): e53485. Available from: http://www.scielo.br/pdf/rgenf/ v37n1/0102-6933-rgenf-1983-144720160153485.pdf

21. Barbiani R, Nora CRD, Schaefer R. Nursing practices in the primary health care context: a scoping review. Rev Latino-Am Enferm [Internet]. 2016 [cited 2018 Jan 19] ; 24: e2721. Available from: http://www.scielo.br/pdf/rlae/v24/pt_0104-1169-rlae-24-02721.pdf 